Ekuitas: Jurnal Pendidikan Ekonomi

Volume 9, Number 2, Tahun 2021, pp. 222-229

P-ISSN : 2354-6107 E-ISSN : 2549-2292

Open Access: https://ejournal.undiksha.ac.id/index.php/EKU

\title{
Pengaruh Akuntabilitas, Transparansi dan Sistem Akuntansi Keuangan Desa dalam Pengelolaan Keuangan Desa
}

\author{
Anggi Alfiani ${ }^{*}{ }^{*}$, Sri Dwi Estiningrum ${ }^{2}$ \\ 1,2Universitas Islam Negeri Sayyid Ali Rahmatullah, Tulungagung -Indonesia
}

\author{
A R T I C L E I N F O \\ Article history: \\ Received June, 272021 \\ Received in revised form \\ September, 82021 \\ Accepted September, 13 \\ 2021 \\ Available online December, \\ 252021

\section{Kata Kunci:} \\ Akuntabilitas, pengelolaan \\ keuangan desa, sistem \\ akuntansi keuangan desa \\ Transparansi. \\ Keywords: \\ Accountability, financial \\ accounting system, \\ transparency, village, village \\ financial management
}

\begin{abstract}
A B S T R A K
Penelitian mengenai akuntabilitas, transparansi serta sistem akuntansi keuangan desa ini dimaksudkan untuk mengetahui pengaruhnya dalam pengelolaan keuangan desa. Penggunaan metode asosiatif dipilih sebagai acuan untuk mengetahui serta menguji apakah terdapat pengaruh antar variabel. Penelitian ini mengambil sampel secara Non-Probabilitas dimana sampel yang ditentukan oleh peneliti sebanyak 70 responden yang terdiri dari warga desa Pule yang memiliki kriteria yang ditentukan oleh peneliti. Data primer dan data sekunder digunakan oleh peneliti untuk menguji antar beberapa variabel, dimana data-data terkait dikumpulkan melalui teknik kuesioner. Hasil penelitian analisis regresi linier berganda menunjukkan adanya pengaruh akuntabilitas, transparansi serta sistem akuntansi keuangan desa dalam pengelolaan keuangan desa yang ada di desa Pule, Kecamatan Pule Kabupaten Trenggalek.
\end{abstract}

\section{A B S T R A C T}

This research on accountability, transparency and village financial accounting system is intended to determine the effect on village financial management. The use of the associative method was chosen as a reference to determine and test whether there is an influence between variables. This study takes a non-probability sample where the sample determined by the researcher is 70 respondents consisting of Pule villagers who have the criteria determined by the researcher. Primary data and secondary data are used by researchers to test between several variables, where related data is collected through questionnaire techniques. The results of the multiple linear regression analysis show that there is an influence of accountability, transparency and village financial accounting systems in managing village finances in Pule village, Pule sub-district, Trenggalek district.

Copyright (C) Ekuitas: Jurnal Pendidikan Ekonomi. All rights reserved.

\footnotetext{
* Corresponding author.

E-mail; anggialviani44@gmail.com (Anggi Alfiani)
} 


\section{Pendahuluan}

Desa diartikan sebagai hunian bagi masyarakat yang memilki tata kelola pemerintahan secara mandiri yang diketuai oleh lurah atau kepala desa (Ali \& Saputra ,2020). Wewenang untuk mengatur dan mengelola sendiri pemerintahan daerah ini tertulis dalam Undang-Undang No. 6 Tahun 2014, adapun undang-undang tersebut memaparkan bahwa desa merupakan daerah otonom yang berarti bahwa pemerintahan yang ada di desa bersifat mandiri (Bender, 2016). Dengan adanya otonomi daerah ini maka menyebabkan desa harus bisa maksimal dalam mengatur tata kelola pemerintah annya serta mengelola keuangannya secara baik agar kesejahteraan masyarakat desa meningkat. Tata kelola keuangan desa tertuang pada Peraturan Pemerintah Dalam Negeri No. 113 Tahun 2014 yang menjelaskan bahwa setiap desa mempunyai kewajiban untuk membuat laporan keuangan terkait penggunaan keuangan desa serta melaporkannya kepada pemerintah daerah setiap satu semester sekali (Kementrian Dalam Negeeri, 2018). Selain itu, pemerintah desa juga memiliki kewajiban untuk membuat laporan keuangan tahunan untuk warga desa yang dapat diinformasikan melalui Badan Perwakilan Desa (BPD) setiap tahun. Adapun kegiatan dalam tata kelola keuangan desa yang telah ditentukan oleh Permendagri Nomor 113 Tahun 2014 dimulai dari merencanakan, menganggarkan, melalukan penatausahaan, melaporkan, mempertanggungjawabkan serta mengawasi keuangan desa.

Tata kelola keuangan desa yang baik dapat diwujudkan apabila kebutuhan akan variabel pendukung terpenuhi. Banyak variabel yang mampu mendukung pengelolaan desa supaya lebih baik, diantaranya adalah akuntabilitas, transparansi, sistem akuntansi keuangan desa, dan sebagainya (BPKP, 2016) . Penelitian ini dilakukan pada saat penggunaan aplikasi siskeudes atau sistem keuangan desa, dimana aplikasi ini membantu pengelola keuangan desa agar lebih mudah (BPKP, 2018). Dalam aplikasi siskeudes ini laporan pengelolaan keuangan desa dan dokumen yang berkaitan dalam penatausahaan bisa didapat ketika pengelola keuangan desa melakukan input sesuai dengan ketentuan yang berlaku (BPKP, 2018).

Akuntabilitas adalah suatu proses dimana seorang pelaksana menjelaskan kebiasaan dan memberikan informasi kepada orang lain, dimana penilaian atas perilaku diberikan sebagai dari peraturan atau gagasan yang telah ditetapkan sebelumnya (M. A. Ali, 2019). Menurut (Ibietan, 2013) akuntabilitas keuangan adalah kewajiban dari pihak pejabat yang menangani sumber daya atau posisi kepercayaan lainnya untuk melaporakn penggunaan sumber daya yang telah dipergunakan.

Transparansi adalah informasi terkait keuangan pemerintah yang harus dikelola dan dipublikasikan tepat waktu dan akurat, lengkap, terkini, andal dan tersedia dalam waktu yang cukup untuk dianalisis serta dievaluasi oleh pemangku kepentingan terkait (Abubakar, Dibal, Amade, \& Joyce, 2017). Dalam Premendagi Tahun 2014 Nomor 113, didalam panduan pengelolaan keuangan daerah, menjelaskan tentang pengertian transparan merupakan suatu ketentuan yang memiliki sifat keterbukaan yang menyalurkan hak kepada para warga untuk bisa mendapatkan serta mengakses informasi secara luas mengenai keuangan daerah (Kementrian Dalam Negeeri, 2018). Sedangkan menurut (Natawibawa, Mulya, \& Yoh, 2019) transparansi adalah suatu kewajiban manajemen untuk memberikan informasi dan mendidik para pengaku kepentingan mereka di luar batas yang mereka terikat secara hukum untuk mengungkapkan informasi.

Sistem akuntansi keuangan desa menurut (Sujarweni, 2014) mengatakan bahwa akuntansi desa adalah proses pencatatan transaksi keuangan desa terkait segala transaksi yang menggunakan dana desa didukung dengan adanya bukti transaksi untuk menghasilkan output laporan keuangan. Sedangkan dalam Peraturan Pemerintah Republik Indonesia No. 24 Tahun 2005 menjelaskan bahwa sistem akuntansi pemerintah merupakan suatu kegiatan yang dimulai dari pengumpulan data-data transaksi yang dilakukan, setelah pengumpulan data transaksi maka pencatatan akan dilakukan,lalu pengikhtisaran dan yang terakhir adalah pelaporan posisi keuangan serta operasi keuangan dalam pemerintahan baik yang dilakukan secara manual maupun terkomputerisasi (Ismail et al., 2016).

Penelitian ini mengambil tiga variabel bebas diantaranya akuntabilitas, transparansi dan sistem akuntansi keuangan desa. Dimana pada penelitian-penelitian yang terdahulu belum ada yang menggunakan 3 variabel ini secara bersamaan. Serta penelitian ini dilakukan ketika sistem keuangan desa sudah menggunakan sebuah aplikasi yang terkomputerisasi bukan secara manual menggunakan kertas, sehingga sistem akuntansi yang ada di desa lebih teliti dari sebelumnya. Dilakukannya oenelitian ini, peneliti mengharap agar aktivitas tata kelola keuangan desa bisa diketahui faktor apa saja yang bisa mempengaruhinya. Sehingga pengelolaan keuangan yang ada di desa Pule bisa semakin baik dari tahuntahun sebelumnya dan pada akhirnya akan berimbas pada kesejahteraan masyarakat desa.

Pada penelitian sebelumnya dilakukan oleh (Sukmawati \& Nurfitriani, 2019) yang dilaksanakan pada pemerintah Desa Garut Kabupaten Garut menyatakan bahwa pengelolan keuangan desa secara signifikan dipengaruhi oleh transparansi dan akuntabilitas. 
Sedangkan sistem akuntansi keuangan desa pernah diteliti oleh (Arfiansyah, 2020) menyatakan bahwa secara signifikan akuntabilitas pengelolaan keuangan desa dipengaruhi oleh sistem akuntansi keuangan desa khususnya tata kelola keuangan dana desa.

Berdasarkan pada pemaparan diatas, penelitian dimaksudkan untuk menguji bagaimana pengaruhnya antara akuntabilitas, transparansi dan sistem akuntansi keuangan desa dalam tata kelola keuangan desa.

\section{Metode}

Penelitian kuantitatif digunakan untuk membentuk sebuah kebenaran yang menunjukkan ikatan ataupun pengaruh serta dapat menjadi perbandingan antara variabel kemudian ada deskripsi statistik, menaksir, menguji teori, dan yang terakhir meramalkan hasilnya (Subagyo, 2017). Penelitian ini melibatkan akuntabilitas, transparansi dan sistem akuntansi keuangan sebagai variabel bebas dan pengelolaan keuangan desa digunakan sebagai varibale terikat.

Penelitian ini tergolong jenis penelitian asosiatif, yaitu salah satu jenis penelitian berfungsi sebagai penambah pengetahuan tentang hubungan yang terjadi pada lebih dari dua variabel, yang selanjutnya dari hasil penelitian yang dilakukan bisa membangun teori yang bisa meramalkan, mengontrol suatu gejala atau masalah serta menjelaskan. Permasalahan asosiatif yang terjadi dalam penelitian ini yaitu masalah mengenai hubungan sebab akibat (kausal) dengan bentuk masalah yang menyatakan bahwa hubungan tersebut memiliki sifat saling mempengaruhi lebih dari dua variabel (Siregar, 2014a) .

Lokasi penelitian yang dipilih oleh peneliti adalah berada di Desa Pule Kecamatan Pule Kabupaten Trenggalek. Lokasi penelitian ini dipilih karena pertimbangan akan pentingnya peningkatan akuntabilitas, transparansi serta sistem akuntansi keuangan desa dalam tata kelola keuangan desa Pule Kecamatan Pule Kabupaten Trenggalek serta pertimbangan lokasi yang jauh dari ibukota provinsi. Sehingga jarak desa yang cukup jauh cukup berisiko terhadap penyelewengan kekuasaan akibat minimnya tingkat akuntanbilitas dan juga transparansi yang rendah sebagai akibat dari pengawasan yang rendah dari pemerintah pusat.

Sumber data merupakan segala informasi yang berguna untuk mendapatkan data. Guna mendapatkan data yang bermanfaat dalam proses penelitian, maka peneliti memakai data primer dan data sekunder untuk mendukung berjalannya proses penelitian. Data yang dihimpun sendiri oleh peneliti dengan tujuan untuk menyelesaikan persoalan yang muncul dari penelitian disebut dengan data primer, sedangkan penyebaran kuesioner atau angket dilakukan peneliti untuk mengumpulkan bukti data atau informasi di dalam penelitiannya. Sedangkan data sekunder adalah berbagai data dan informasi yang telah tersedia disuatu lembaga tanpa harus melakukan pengumpulan data terlebih dahulu untuk dapat melihat data yang dibutuhkan untuk melengkapi penelitian. Profil desa, jumlah penduduk desa dan tingkat pendidikan penduduk desa yang terdapat pada balai desa digunakan peneliti sebagai data sekunder.

Populasi adalah suatu gejala sosial, sekelompok orang maupun kejadian yang memiliki karakteristik tertentu (Siregar, 2014b). Warga Desa Pule Kecamatan Pule Kabupaten Trenggalek merupakan populasi yang digunakan peneliti untuk melakukan penelitian.

Bagian dari populasi yang terpilih melalui pertimbangan-pertimbangan tertentu serta dianggap mampu mewakili populasi disebut dengan sampel (Supardi, 2005). Teknik pengambilan sampel yang dilakukan peneliti adalah menggunakan Non-Probabilitas sampel, dimana sampel diambil sesuai dengan karateristik yang sudah dibuat oleh peneliti. Sampel dari penelitian yang dilakukan oleh peneliti disini adalah warga Desa Pule yang telah menempuh pendidikan minimal Sarjana, dimana jumlah keseluruhan sampel dalam sejumlah 70 orang/sampel yang diambil dari rumus Slovin dimana tingkat kesalahan atau Margin Error yang digunakan adalah 10\% dari total keseluruhan 305 sampel.

Untuk mengetahui hubungan atau pengaruh yang terjadi antara akuntabilitas, transparansi dan sistem akuntansi keuangan desa dalam tata kelola keuangan desa, maka analisis regresi linier berganda serta uji asumsi klasik dipilih serta dimanfaatkan untuk melakukan pemecahan masalah yang timbul dalam penelitian ini. 


\section{Hasil dan Pembahasan \\ a. Hasil}

Uji normalitas merupakan analisis statistik yang berguna untuk menguji serta mengetahui normal tidaknya distribusi yang terjadi pada model regresi atapun variabel pengganggu. Model regresi terdistribusi normal ketika garis diagonal diikuti oleh titik-titik (plotting) yang menggambarkan data sesungguhnya (Ghozali, 2011). Uji normalitas disajikan dalam gambar 1 dibawah ini :

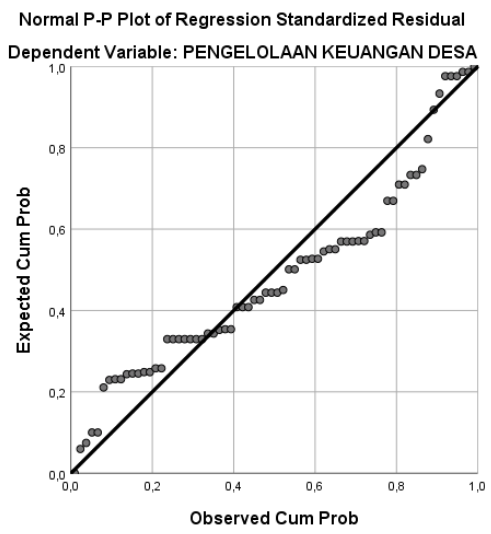

Gambar 1. Hasil Uji Normalitas

Gambar 1 menjelaskan tentang data yang terdapat pada penelitian yang dilakukan dinyatakan normal karna garis diagonalnya diikuti oleh titik-titik data plotiing (model regresi terdistribusi normal).

Untuk membuktikan bahwa dalam suatu penelitian tidak diketahui korelasi antar variabel bebas, maka selanjutnya pengujian multikolonieritas dilakukan. Perlu diketahui bahwa model regresi yang tidak memunculkan korelasi antara variabel bebas telah dianggap baik. Perbandingan nilai tolerance dan nilai VIF (Varians Inflation Factor digunakan sebagai syarat untuk mendapati adanya indikasi multikolinieritas. Menurut (Ghozali, 2011) ketika nilai Tolerance tidak kurang 0,100 serta nilai VIF tidak lebih 10 , maka bisa dikatakan bahwa tidak terindikasi adanya multikolinieritas. Hasil uji multikolonieritas disajaikan dalam tabel 1:

Tabel 1. Hasil Uji Multikolinieritas

Coefficients $^{\mathbf{a}}$

\begin{tabular}{|c|c|c|c|c|c|c|c|}
\hline \multirow[b]{2}{*}{ Model } & \multicolumn{2}{|c|}{$\begin{array}{c}\text { Unstandardized } \\
\text { Coefficients }\end{array}$} & $\begin{array}{c}\text { Standardize } \\
\mathrm{d} \\
\text { Coefficients }\end{array}$ & \multirow[t]{2}{*}{$\mathrm{T}$} & \multirow[t]{2}{*}{ Sig. } & \multicolumn{2}{|c|}{$\begin{array}{c}\text { Collinearity } \\
\text { Statistics } \\
\end{array}$} \\
\hline & B & Std. Error & Beta & & & $\begin{array}{l}\text { Toleranc } \\
\mathrm{e}\end{array}$ & VIF \\
\hline 1 (Constant) & 3,189 & 1,752 & & 1,821 & ,073 & & \\
\hline AKUNTABILITAS & ,295 & ,069 & 467 & 4,270 & ,000 & 299 & 3,342 \\
\hline TRANSPARANSI & 348 & ,043 & 654 & 8,072 & ,000 & ,544 & 1,838 \\
\hline $\begin{array}{l}\text { SISTEM AKUNTANSI } \\
\text { DESA }\end{array}$ & -292 & 144 &,- 211 & $-2,029$ & 047 & ,329 & 3,037 \\
\hline
\end{tabular}

a. Dependent Variable: Pengelolaan Keuangan Desa

Sumber : Data Primer Diolah, 2021

Tabel 1 telah ditunjukkan nilai uji multikolinieritas dari ketiga variabel bebas. Berikut ini adalah nilai tolerance dan VIF yang ada dalam penelitian: 1) Akuntabilitas nilai tolerancenya 0,299 dan VIF 3,342. 2) Transparansi menunjukkan nilai tolerancenya 0,544 dan VIF-nya 1,838. 3) Sistem Akuntansi Keuangan Desa nilai tolerancenya 0,329 dan VIF-nya 3,037. Jadi, sebagaimana dasar pengambilan keputusan yang telah diungkapkan oleh (Ghozali, 2011) maka kesimpulan uji multikolinieritas dari ketiga variabel bebas tersebut dinyatakan bahwa gejala multikolinieritas pada penelitian yang dilakukan oleh peneliti tidak ditemukan atau tidak terindikasi. 
Uji heteroskedastisitas berguna dalam membuktikan ketidaksamaan varian dalam satu penelitian ke penlitian lainnya, apakah terjadi atau tidak dalam model regresi. Pengujian kemungkinan adanya heteroskedastisitas dilakukan menggunakan analisis grafik Scatter Plot. Ketika titik-titik pada hasil uji heteroskedastisitas tersebar pada bagian atas dan bagian bawah angka 0 pada sumbu vertikal (Y) dan model atau pola yang terbentuk dari titik-titik ini tidak menggambarkan pola yang jelas maka bisa dikatakan bahwa tidak terindikasi heteroskedastisitas (Ghozali, 2011). Gambar 2 adalah sajian dari uji heteroskedastisitas:

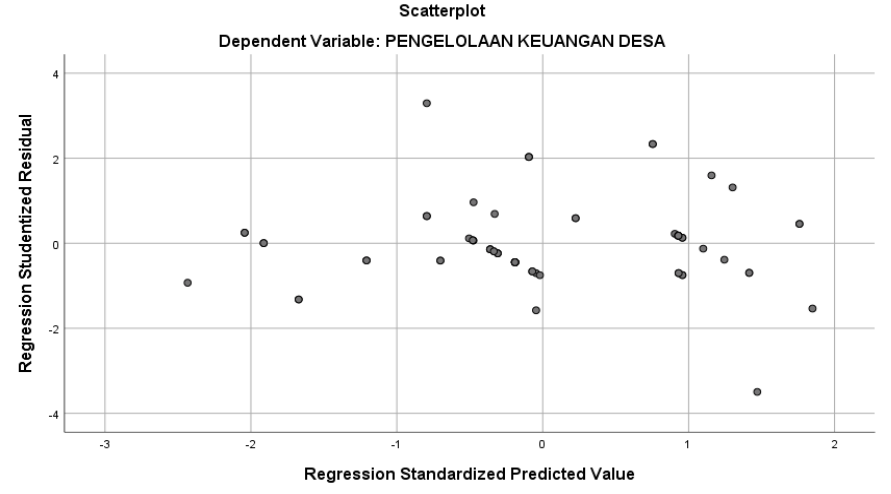

Gambar 2. Uji heteroskedastisitas

Terlihat pada gambar 2, sumbu y banyak titik yang terbentuk berada diatas dan dibawah angka 0 dan pola yang terbentuk pada uji Scatter Plot tidak terbentuk secara jelas. Berdasarkan pada konsep yang telah dijabarkan, dapat disimpulkan bahwa tidak adanya gejala heteroskedastisitas.

Analisis regresi linier berganda dimanfaatkan untuk mendeteksi adanya pengaruh yang terjadi diantara lebih dari dua variabel bebas $(\mathrm{X})$ pada variabel terikat $(\mathrm{Y})$. Regresi linier berganda menggunakan 2 uji analisis. Uji t-Parsial adalah salah satu uji yang dimanfaatkan dalam analisis regresi linier berganda dimana kegunaan dari uji t-Parsial ini adalah untuk membuktikan ada atau tidaknya pengaruh variabel bebas $(\mathrm{X})$ terhadap variabel terikat (Y) secara mandiri. Tabel 2 berikut ini menunjukkan hasil uji regresi linier berganda dengan uji t-Parsial :

Tabel 2. Hasil Regresi Linier Berganda Untuk Uji t-Parsial

Coefficients $^{\mathbf{a}}$

\begin{tabular}{|c|c|c|c|c|c|c|c|c|}
\hline \multirow{2}{*}{\multicolumn{2}{|c|}{ Model }} & \multicolumn{2}{|c|}{$\begin{array}{l}\text { Unstandardized } \\
\text { Coefficients }\end{array}$} & \multirow{2}{*}{$\begin{array}{c}\begin{array}{c}\text { Standardiz } \\
\text { ed } \\
\text { Coefficient } \\
\text { S }\end{array} \\
\text { Beta }\end{array}$} & \multirow[t]{2}{*}{$\mathrm{t}$} & \multirow[t]{2}{*}{ Sig. } & \multicolumn{2}{|c|}{$\begin{array}{c}\text { Collinearity } \\
\text { Statistics }\end{array}$} \\
\hline & & $\mathrm{B}$ & Std. Error & & & & $\begin{array}{c}\text { Toleran } \\
\text { ce }\end{array}$ & VIF \\
\hline \multirow[t]{4}{*}{1} & (Constant) & 3,189 & 1,752 & & 1,821 & ,073 & & \\
\hline & AKUNTABILITAS & ,295 & ,069 & ,467 & 4,270 & ,000 & 299 & 3,342 \\
\hline & TRANSPARANSI & ,348 & ,043 & ,654 & 8,072 & ,000 &, 544 & 1,838 \\
\hline & $\begin{array}{l}\text { SISTEM } \\
\text { AKUNTANSI DESA }\end{array}$ &,- 292 & 144 &,- 211 & $-2,029$ &, 047 & ,329 & 3,037 \\
\hline
\end{tabular}

a. Dependent Variable: Pengelolaan Keuangan Desa

Sumber : Data Primer Diolah, 2021

Dalam uji t-Parsial apabila nilai signifikansi berada dibawah angka 0,05 maka variabel bebas tersebut bisa dikatakan bahwa variabel terikat didominasi oleh variabel bebas. Selain itu menurut (Sujarweni, 2014) menyatakan bahwa apabila dari nilai t tabel dibawah dari nilai t hitung maka variabel independent $(\mathrm{X})$ mempengaruhi variabel dependent $(\mathrm{Y})$ secara mandiri atau parsial. Pada penelitian ini bisa dilihat bahwa nilai signifikansi yang didapat untuk variabel bebasnya adalah sebagai berikut : akuntabilitas 0,000, transparansi 0,000, dan sistem akuntansi desa 0,047. Jadi, dari ketiga variabel bebas tersebut dapat dikatakan memiliki pengaruh atau berpengaruh terdapat variabel terikat karena nilai signifikansi yang dimiliki ketiganya berada dibawah 0,05. 
Sehingga, dapat disimpulkan dari nilai t-hitung yang diperoleh dari ketiga variabel bebasnya yaitu akuntabilitas nilai t-hitungnya sebesar 4,270, transaparansi sebesar 8,072 dan sistem akuntansi keuangan desa sebesar -2,029, sedangkan nilai t-tabelnya sebesar 1,996. Sehingga bisa dikatakan bahwa pengelolaan keuangan desa dipengaruhi secara positif oleh variabel akuntabilitas, variabel transparansi juga mempengaruhi secara positif pada tata kelola keuangan desa, sedangkan sistem akuntansi keuangan desa mempengaruhi tata kelola keuangan desa namun secara negatif.

Selain menggunakan uji t-Parsial, dalam regresi linier berganda juga menggunakan uji F-Simultan yang digunakan sebagai alat analisis dengan maksut untuk membuktikan ada atau tidaknya pengaruh secara beriringan (simultan) antara variabel independent dengan variabel dependent. Perlu diketahui bahwa untuk menyatakan pengaruh tidaknya variabel independent atas variabel dependent maka suatu penelitian harus mempunyai nilai signifikan (sig.) dibawah angka 0,05(Ghozali, 2011). Untuk mengetahui hasil uji F-Simultan dari penelitian ini maka ditampilkan dalam tabel 3 berikut ini:

Tabel 3. Hasil Uji Regresi Linier Berganda untuk Uji F-Simultan

ANOVA ${ }^{a}$

\begin{tabular}{ccccccc}
\hline & & Sum of & & & & \\
& Model & Squares & Df & Mean Square & F & Sig. \\
\hline 1 & Regression & 287,465 & 3 & 95,822 & 71,191 &, $000^{\mathrm{b}}$ \\
& Residual & 88,835 & 66 & 1,346 & & \\
& Total & 376,300 & 69 & & & \\
\hline
\end{tabular}

a. Dependent Variable: Pengelolaan Keuangan Desa

b. Predictors: (Constant), Sistem Akuntansi Desa, Transparansi, Akuntabilitas

Sumber: Data Primer Diolah, 2021

Jika dicermati pada tabel 3 diketahui bahwa nilai signifikansi secara simultan untuk variabel akuntabilitas (X1), transaparansi (X2) dan sistem akuntansi keuangan desa (X3) adalah sebesar 0,00 dan F hitungnya 71,191 hal ini membuktikan bahwa nilai signifikansi ada dibawah nilai 0,05 dan nilai $\mathrm{f}$ tabel lebih kecil daripada nilai f hitung. Maka bisa dinyatakan bahwa pengaruh antara akuntabilitas (X1), transparansi (X2) dan sistem akuntansi keuangan desa (X3) secara simultan dalam pengelolaan keuangan $\operatorname{desa}(\mathrm{Y})$.

Koefisien determinasi adalah sebuah angka yang menunjukkan berapa persen pengaruh yang terjadi antara variabel bebas pada variabel terikat. Koefisien determinasi bermanfaat sebagai alat untuk menilai seberapa besar variabel independent dipengaruhi oleh variabel dependent, sehingga dalam penelitian ini tujuan dari koefisien determinasi adalah untuk mengukur seberapa detail pengelolan keuangan desa dijelaskan oleh Akuntabilitas, Transparansi dan Sistem Akuntansi Keuangan Desa. Dalam tabel 4 dibawah ini menunjukkan output untuk hasil uji koefisien determinasi:

Tabel 4. Hasil Uji Koefisien Determinasi Model Summary

\begin{tabular}{ccccc}
\hline Model & $\mathrm{R}$ & R Square & $\begin{array}{c}\text { Adjusted R } \\
\text { Square }\end{array}$ & $\begin{array}{c}\text { Std. Error of the } \\
\text { Estimate }\end{array}$ \\
\hline 1 &, $874^{\mathrm{a}}$ &, 764 &, 753 & 1,160 \\
\hline
\end{tabular}

a. Predictors: (Constant), Sistem Akuntansi Desa, Transparansi, Akuntabilitas

b. Dependent Variable: Pengelolaan Keuangan Desa

Dalam tabel 4 diatas dapat disimpulkan variabel Akuntabilitas (X1), Transparansi (X2) dan Sistem Akuntansi Keuangan Desa (X3) mempengaruhi Pengelolaan Keuangan Desa sejauh 76,4\% karena nilai R Square yang ditunjukkan pada tabel $=0,764$.

\section{b. Pembahasan}

Serangkaian kegiatan yang diawali dari proses merencanakan, melaksanakan, melakukan tata usaha, dan diakhiri dengan melaporkan serta mempertanggungjawabkan yang harus dilakukan oleh pemerintah desa, disebut dengan kegiatan pengelolaan keuangan desa (Hasanah, Nurhayati, \& Purnama, 2020). Untuk mewujudkan pengelolan keuangan desa yang baik, maka banyak faktor yang 
mempengaruhi proses pengelolaan keuangan desa diantaranya, akuntabilitas, transaparansi, sistem akuntansi keuangan desa, dan sebagainya.

Hasil dari penelitian diatas, menyatakan bahwa variabel Akuntabilitas (X1) terdapat pengaruh positif signifikan dalam pengelolaan keuangan desa. Hal ini terjadi karena pada hasil uji t-Parsial nilai signifikan yang diperoleh untuk variabel akuntabilitas adalah sebesar $0,000<$ dari 0,05 sehingga variabel akuntabiltas bisa dikatakan mempengaruhi variabel terikat yaitu pengelolaan keuangan desa. Sedangkan nilai t-hitung yang dimiliki oleh variabel akuntabilitas adalah sebesar 4,270 dan nilai t-tabelnya adalah 1,996. Karena nilai t-hitung diatas nilai t-tabel, sehingga bisa dikatakan bahwa variabel akuntabilitas mempengaruhi variabel pengelolaan keuangan desa. Dengan adanya akuntabilitas dalam pengelolaan keuangan desa, maka diharapkan pengelola keuangan desa bisa lebih berhati-hati dalam melakukan pengelolaan keuangan desa mengingat pengelola keuangan desa memiliki tanggungjawab untuk memaparkan laporan hasil kerjanya kepada penduduk desa. Hasil akhir dari penelitian ini sependapat dengan penelitian yang pernah dikerjakan oleh (Umami \& Nurodin, 2017), (Sukmawati \& Nurfitriani, 2019) yang menunjukkan bahwa akuntabilitas memiliki pengaruh positif signifikan atas tata kelola keuangan desa.

Begitu juga pada variabel Transparansi (X2) yang menunjukkan hasil bahwa nilai signifikansi yang didapatkan dalam uji t-parsial adalah senilai $0,000<0,005$ sehingga bisa dinyatakan bahwa variabel transparansi mempengaruhi secara signifikan terhadap pengelolaan keuangan bebas. Sedangkan nilai thitung variabel transparansi adalah 8,072 serta nilai t-tabel adalah sebesar 1,996 sehingga bisa disimpulkan bahwa variabel transparansi mempengaruhi secara positif terhadap pengelolaan keuangan desa. Jadi, ketika transparansi semakin baik, maka pengelolaan keuangan diharapkan semakin baik pula karena pemerintah desa akan merasa memilki tanggung jawab untuk bersifat transparan atau terbuka terhadap tata kelola pemerintahannya. Hasil dari variabel ini juga sama dengan penelitian yang pernah dilakukan oleh (Umami \& Nurodin, 2017), (Sukmawati \& Nurfitriani, 2019) yang membuktikan bahwa variabel transparansi memiliki pengaruh dalam pengelolaan keuangan desa secara signifikan.

Berbeda dengan variabel akuntabilitas dan transaparansi, maka variabel sistem akuntansi keuangan desa menunjukkan bahwa adanya pengaruh negatif signifikan dari variabel sistem akuntansi keuangan desa pada pengelolaan keuangan desa. Hal ini disebabkan oleh nilai t-hitung yang diperoleh untuk variabel sistem akuntansi keuangan desa adalah sebesar -2,029 dan nilai t-tabelnya adalah 1,996 hal ini berarti nilai t tabel< nilai t-hitung, sedangkan nilai signifikansinya adalah 0,047<0,05. Hasil penelitian ini sependapat dengan penelitian yang pernah dilaksanakan oleh (Arfiansyah, 2020) yang mengutarakan bahwa secara signifikan tata kelola keuangan desa dipengaruhi oleh sistem akuntansi keuangan desa.

Ketika akuntabilitas dan transaparansi dilakukan dengan maksimal maka akan mampu mendorong terciptanya pengelolaan keuangan desa yang lebih baik pula, karena pengelola keuangan desa akan merasa diawasi oleh masyarakat serta pengelola keuangan desa akan merasa mempunyai tanggung jawab untuk memberikan informasi, pertanggungjawaban serta pelaporan tentang pengelolaan keuangan desa terhadap masyarakat dan juga pemerintah pusat. Sedangkan sistem akuntansi keuangan desa ketika diterapkan secara maksimal dapat membantu pengelola keuangan desa untuk menyusun laporan keuangan serta laporan pertangungjawaban secara lebih lengkap dan terperinci sejalan dengan pedoman yang sudah ditentukan oleh pemerintahan pusat. Begitu pula yang terjadi pada Desa Pule, Kecamatan Pule Kabupaten Trenggalek dimana akuntabilitas, transparansi dan sistem akuantansi keuangan desa telah dilaksanakan secara baik hal ini terbukti pada laporan keuangan desa yang selalu ditampilkan dalam bentuk baliho besar yang diletakkan didepan kantor desa.

\section{Simpulan dan Saran}

\section{a. Simpulan}

Penelitian tentang pengaruh akuntabilitas, transparansi dan sistem akuntansi keuangan desa dalam pengelolaan keuangan desa yang dilaksanakan pada Desa Pule Kecamatan Pule Kabupaten Trenggalek, didapatkan hasil bahwa pengelolaan keuangan desa dipengaruhi secara positif oleh variabel akuntabilitas dan transparansi, sedangkan variabel sistem keuangan desa mempengaruhi secara negatif. Dan secara simultan dapat disimpulkan bahwa akuntabilitas, transparansi dan sistem akuntansi keuangan desa mempengaruhi pengelolaan keuangan desa yang ada di desa Pule.

\section{b. Saran}


Penelitian ini merekomendasikan pada pihak yang melakukan tata kelola keuangan desa yang dilaksanakan oleh setiap pemerintahan yang ada di desa, khususnya Desa Pule Kecamatan Pule Kabupaten Trenggalek, untuk selalu mematuhi dan melaksanakan Peraturan Permendagri yang berlaku supaya tata kelola keuangan desa bisa berjalan lebih baik.

Dan untuk peneliti yang akan datang, karena terbatasnya jumlah responden dalam penelitian ini, saya sebagai peneliti berharap supaya peneliti selanjutnya bisa melakukan penambahan jumlah responden dan juga penambahan variabel-variabel lain yang mungkin memilki pengaruh terhadap pengelolaan keuangan desa.

\section{Daftar Rujukan}

Abubakar, A. A., Dibal, N. A., Amade, P., \& Joyce, P. (2017). Effect of Internal Control Activity on Financial Accountability and Transparency in Local Government Areas of Borno State, Nigeria. European Journal of Business and Management Www.liste.Org ISSN, 9(30), 58-65. Retrieved from www.iiste.org

Ali, K., \& Saputra, A. (2020). Tata Kelola Pemerintahan Desa Terhadap Peningkatan Pelayanan Publik Di Desa Pematang Johar. Warta Dharmawangsa, 14(4), 602-614. https://doi.org/10.46576/wdw.v14i4.891

Ali, M. A. (2019). Assessing the Financial Accountability of the Puntland State of Somalia Government Organizations. European Journal of Business and Management, 11(34), 7-12. https://doi.org/10.7176/ejbm/11-34-02

Arfiansyah, M. A. (2020). Pengaruh Sistem Keuangan Desa dan Sistem Pengendalian Intern Pemerintah Terha- dap Akuntabilitas Pengelolaan Dana Desa. Journal of Islamic Finance and Accounting, 3(1), 67-82. Retrieved from http://ejournal.iainsurakarta.ac.id/index.php/jifa/article/view/2369

Bender, D. (2016). DESA - Optimization of variable structure Modelica models using custom annotations. ACM International Conference Proceeding Series, 18-April-2(1), 45-54. https://doi.org/10.1145/2904081.2904088

BPKP. (2016). Buku Kerja Aplikasi Sistem Keuangan Desa (SISKEUDES). BOGOR.

BPKP. (2018). Pedoman Siskeudes. Bpkp.Go.Id, 3. Retrieved from http://www.bpkp.go.id/public/upload/unit/sakd/files/Pedoman_Keudesa(4).pdf

Ghozali, I. (2011). aplikasi analisis multivariate dengan program spss. semarang: badan penerbit universitas diponegoro.

Hasanah, S., Nurhayati, E., \& Purnama, D. (2020). Akuntabilitas Pengelolaan Keuangan Desa: Studi Pada Pemerintah Desa di Kecamatan Cibeureum Kabupaten Kuningan. Reviu Akuntansi Dan Bisnis Indonesia, 4(1), 17-27. https://doi.org/10.18196/rab.040149

Ibietan, J. (2013). Corruption and Public Accountability in the Nigerian Public Sector: Interrogating the Omission . 5(15), 41-49.

Ismail, M., Widagdo, A. K., \& Widodo, A. (2016). Sistem Akuntansi Pengelolaan Dana Desa. Jurnal Ekonomi Dan Bisnis, 19(2), 323-340.

Kementrian Dalam Negeeri. (2018). Permendagri No 113. Republik Indonesia, 51(1), 51.

Natawibawa, I. W. Y., Mulya, I. M. O., \& Yoh, W. H. (2019). Transparency and Accountability As Determinants in the Financial Management of Universities: a Study on State Universities in Malang City. Jurnal Tata Kelola Dan Akuntabilitas Keuangan Negara, 5(1), 57-72. https://doi.org/10.28986/jtaken.v5i1.247

Siregar, S. (2014a). Statistik Parametrik untuk Penelitian Kuantitatif : dilengkapi Dengan Perhitungan Manual dan Aplikasi SPSS Versi 17. jakarta: PT. Bumi Aksara.

Siregar, S. (2014b). Statistika Deskriptif untuk Penelitian. jakarta: PT. Raja Grafindo Persada.

Subagyo, R. (2017). Metode Penelitian Ekonomi Islam : Konsep dan Penerapan. Jakarta: Alim's Publishing.

Sujarweni, V. W. (2014). Metode Penelitian : Lengkap, Praktis, dan Mudah Dipahami. Yogyakarta: Pustaka Baru Press.

Sukmawati, F., \& Nurfitriani, A. (2019). Pengaruh Transparansi dan Akuntabilitas terhadap Pengelolaan Keuangan Desa ( Studi pada Pemerintah Desa di Kabupaten Garut ). Jurnal Ilmiah Bisnis, Pasar Modal, Dan UMKM, 2(1), 52-66.

Supardi. (2005). Metodologi Penelitian Ekonomi dan Bisnis. Yogyakarta: UI Press.

Umami, R., \& Nurodin, I. (2017). Pengaruh Transparansi Dan Akuntabilitas Terhadap Pengelolaan Keuangan Desa. Jurnal Ilmiah Ilmu Ekonomi, 6(11). 